Луцик Галина

викладач кафедри вікової та педагогічної психології Рівненського державного гуманітарного університету https://orcid.org/0000-0003-3905-2038

DOI https://doi.org/10.35619/praprv.v1i16.228

\title{
ПСИХОЛОГО-ПЕДАГОГІЧНИЙ ПОТЕНЦАЛ ДИСЦИПЛІНИ «ПСИХОЛОГІЯ ВАЖКОВИХОВУВАНИХ» В АСПЕКТІ ПІДГОТОВКИ МАЙБУТНІХ ПСИХОЛОГІВ ДО РОБОТИ 3 ПІДЛІТКАМИ ДЕВІАНТНОЇ ПОВЕДІНКИ
}

Анотація. У статті аналізується зміст когнітивного компонента готовності майбутніх психологів до професійної діяльності, розглядаються його показники у структурі готовності майбутніх психологів до роботи з підлітками, схильними до девіантної поведінки. Висвітлено результати проведеного дослідження рівнів обізнаності майбутніх психологів із проблемою девіантної поведінки підлітків. У зв'язку з тим, щуо рівень розвитку когнітивного компонента готовності майбутніх психологів до роботи з підлітками, схильними до девіантної поведінки, є недостатнім для ефективної роботи з ними, процес підготовки здобувачів у закладах вищої освіти потребує вдосконалення. Визначено, щзо однією з психолого-педагогічних умов формування готовності майбутніх психологів до роботи зазначеного напрямку є поетапне збагачення змісту професійної підготовки на основі інтеграції психолого-педагогічного потенціалу наявних в освітній програмі навчальних дисциплін та спецкурсів.

На основі аналізу наукових праць виявлено, щзо важковиховуваність у сучасній психологічній літературі розглядається як окрема форма девіантної поведінки. Констатовано, щзо викладання навчальної дисципліни «Психологія важковиховуваних» має значний психолого-педагогічний потенщіал у процесі формування готовності майбутніх психологів до роботи з підлітками, схильними до девіантної поведінки. Як засвідчили результати повторної діагностики рівнів обізнаності майбутніх психологів з проблемою девіантної поведінки підлітків, зміст навчальної дисципліни розцирює знання здобувачів щуодо сутності девіантної поведінки, знайомить з основними формами $i$ методами психодіагностичної, профілактичної, консультативної та психокорекційної роботи 3 девіантами.

Ключові слова: підлітки, девіантна поведінка психолого-педагогічний потенціал навчальної дисиипліни, важковиховувані, психологія важковиховуваних.

Постановка проблеми. В умовах зростання соціального напруження в українському суспільстві посилюються тенденції до виникнення відхильної поведінки. Значною мірою ці тенденції торкнулись поведінки підлітків, найбільш схильних до проявів девіацій. У зв'язку з цим зростає важливість проблеми психологічної допомоги цій категорії підростаючого покоління, що водночас актуалізує проблему підготовки фахівців для успішної реалізації такої роботи. I хоча вища школа володіє широкими можливостями якісної професійної підготовки психологів у зазначеному напрямі, її змістовий потенціал реалізований ще не повною мірою. Адже досягнення результату в цьому напрямі потребує глибокого розуміння особистості девіанта, причин його поведінкових відхилень, можливостей їх корекції.

Аналіз останніх досліджень 3 проблеми. Розв'язанню проблеми якісної підготовки здобувачів до роботи в означеному напрямку сприяють праці Баркаєвої (2009), присвячені дослідженню соціально значущого питання підготовки майбутніх психологів до роботи 3 девіантними підлітками. У контексті порушеної проблеми привертають увагу праці, у яких розкриваються питання професійної підготовки майбутніх психологів в закладах вищої освіти, наголошується на важливості вироблення у них грунтовної системи професійно необхідних знань (Бондаренко; Вірна; Водопьянов; Дуткевич, 2016; Затворнюк, 2016; 
Сердюк, 2018; Чаплак, 2006). Водночас привертають інтерес наукові роботи вчених (Драч, Чернишова, 2010; Куцевол; Смолінська; Ясіновська), котрі аналізують можливості підвищення результативності навчання здобувачів вищої освіти шляхом удосконалення змісту освіти, забезпечення його «адекватності ... функціям і задачам діяльності майбутнього фахівця» (Драч, Чернишова, 2010, с. 7). Тому, незважаючи на певні досягнення у вивченні процесу підготовки майбутніх психологів до професійної діяльності, практика свідчить про те, що треба активізувати пошук можливостей вдосконалення змістового аспекту підготовки майбутніх психологів до роботи з підлітками, схильними до девіантної поведінки, шляхом інтеграції з навчальними дисциплінами, які розкривають особистісні та поведінкові характеристики важковиховуваних дітей.

Мета статті. Обгрунтувати психолого-педагогічний потенціал дисципліни «Психологія важковиховуваних» у формуванні когнітивного компонента готовності майбутніх психологів до роботи з підлітками, схильними до девіацій.

Виклад основного матеріалу дослідження. Зважаючи на особистісні та поведінкові відхилення, підлітки, схильні до девіантної поведінки, потребують психологічного супроводу в процесі їх адаптації до соціального середовища. Очевидним є те, що актуальною $\epsilon$ спеціальна підготовка майбутніх психологів до роботи у вказаному напрямку. В контексті проблеми, Чаплак (2006) зауважує, що професійну підготовку майбутніх психологів слід здійснювати з урахуванням вимог психологічної діяльності. Такий підхід, на думку автора, забезпечує суб'єкт-суб'єктну взаємодію з клієнтом (Чаплак, 2006, с. 19). Якість надання психологічної допомоги клієнтам значною мірою залежить від обізнаності фахівця 3 проблемою, рівня сформованості когнітивного компонента готовності до роботи 3 підлітками-девіантами. Рівень теоретичної підготовки майбутніх психологів до професійної діяльності залежить від наявності у них критичного мислення, професійно-орієнтованих знань (Сердюк, 2018), розширення професійного кругозору, вироблення і закріплення професійно значущих умінь і навичок (Затворнюк, 2016), сформованої системи загальних та спеціальних знань (Ковалькова, 2016).

Вважаємо, що зміст когнітивного компонента готовності майбутніх психологів до роботи з підлітками, схильними до девіантної поведінки, розкривають такі показники (рис.1).

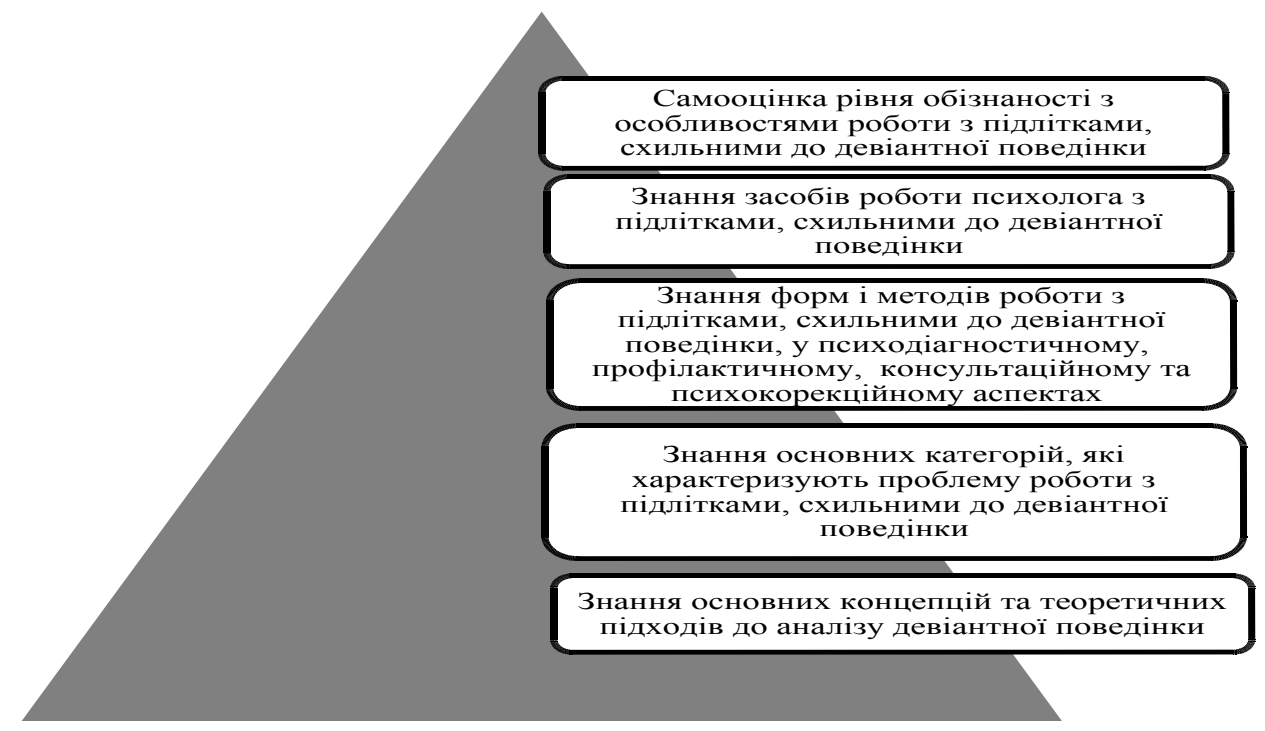

\section{Рис. 1. Зміст когнітивного компонента готовності майбутніх психологів до роботи з підлітками, схильними до девіантної поведінки}

Задля перевірки рівня обізнаності здобувачів вищої освіти 3 проблемою девіантної поведінки підлітків та особливостей роботи з ними було проведено опитування студентів 2 курсу спеціальності «Психологія». Для аналізу рівнів сформованості когнітивного компонента готовності майбутніх психологів до роботи 3 девіантами за виокремленими 
показниками нами були використано комплексний опитувальник щодо обізнаності майбутніх психологів зі змістом та особливостями роботи з підлітками, схильними до девіантної поведінки та анкетування, спрямоване на вивчення самооцінки обізнаності майбутніх психологів 3 особливостями роботи 3 підлітками-девіантами). Комплексний опитувальник дав змогу оцінити рівень сформованості знань, умінь та навичок, здобутих майбутніми психологами на етапі навчання у закладі вищої освіти, зокрема перевірити їх обізнаність з проблемою девіантної поведінки підлітків. Опитувальник складався з чотирьох блоків питань, розміщених у певній послідовності, відповідно до виокремлених показників. Перший блок опитувальника включав питання, призначені для перевірки знання концепцій та теоретичних підходів до вивчення девіантної поведінки у психологічній науці. Другий охоплював питання, спрямовані на виявлення рівня розуміння здобувачами вищої освіти сутності категорій «девіантність», «девіація», «девіантна поведінка», «підлітки девіантної поведінки» тощо. Третій блок питань був присвячений перевірці рівня знань студентів про основні напрями роботи психолога (психодіагностична, профілактична, консультативна та психокорекційна) та особливостей їх застосування у взаємодії з підлітками-девіантами. Четвертий блок питань уможливлював оцінку обізнаності майбутніх психологів із засобами організації зазначених напрямів роботи 3 підлітками-девіантами (включаючи дистанційні засоби в умовах карантинних обмежень). Питання, включені до комплексного опитувальника, були сформульовані у формі тестових завдань різних видів (з множинним вибором, відновлення послідовності, завдання з вибором трьох правильних відповідей, завдання на встановлення відповідності тощо).

Як засвідчив аналіз результатів проведеного тестування, значна частина опитаних (36 \%) досить поверхово орієнтувались у питаннях, стосовно причин та особливостей девіантної поведінки, можливостей психодіагностичної, профілактичної, консультативної та психокорекційної роботи з підлітками, схильними до девіації (див. рис. 2).

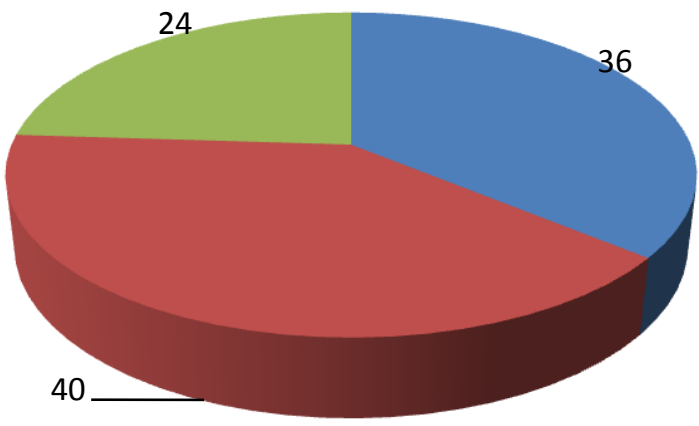

шизький рівень

передній рівень

високий рівень

\section{Рис. 2. Рівні обізнаності здобувачів вищцої освіти з проблемою девіантної поведінки підлітків (у\%)}

За результатами анкетування нами було встановлено, що близько половини здобувачів (48\%) вважали наявні у них знання щодо проблеми девіантної поведінки недостатніми для майбутньої роботи 3 девіантами, а 28 \% респондентів -оцінили рівень своїх знань як низький. Причину низького рівня знань здобувачі бачили у недостатній кількості аудиторних годин, відведених на вивчення основних категорій, що стосуються девіантної поведінки та іiі особливостей у підлітковому віці зокрема. Як наслідок, 40 \% здобувачів вважали доцільним включення до навчальних планів дисциплін, які б систематизували та розширили їх знання щодо порушеної проблеми, оскільки вважають їі актуальною для майбутньої професійної діяльності. У результаті опитування було визначено такі рівні самооцінки обізнаності майбутніх психологів 3 особливостями роботи 3 підлітками, схильними до девіантної поведінки (рис. 3). 


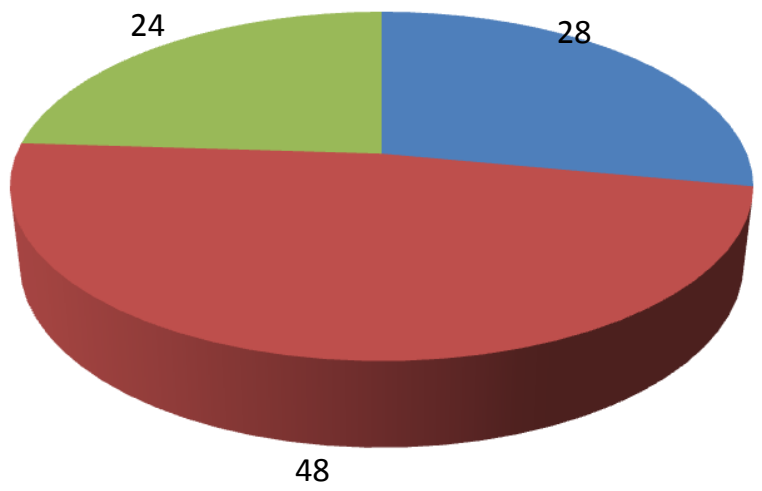

низький рівень

середній рівень

високий рівень

\section{Рис. 3. Обізнаність майбутніх психологів з особливостями роботи з підлітками, схильними до девіантної поведінки (у \%)}

Таким чином, отримані дані засвідчили недостатній рівень обізнаності здобувачів вищої освіти з проблемою девіантної поведінки у підлітковому віці. У контексті розв'язання досліджуваної проблеми бачиться доцільним використати психолого-педагогічний потенціал розробленої нами навчальної дисципліни «Психологія важковиховуваних», внесеної до вибіркової частини навчального плану підготовки майбутніх психологів. Проблема важковиховуваності є важливим питанням для психолого-педагогічної науки. У сучасних дослідженнях прийнято відносити до категорії важковиховуваних дітей та підлітків 3 певними порушеннями розвитку особистості та деструктивною поведінкою. Тому більшість дослідників розглядають важковиховуваність як одну 3 форм девіантної поведінки, що проявляється у низькому рівні адаптивності особистості, порушенні процесу самоактуалізації, зниженні морального та етичного контролю за власною поведінкою (Дорогіна, 2004, с. 17), конфліктності (Тараненко, 2015), агресивності (Орос, 2012) тощо.

Мета розробленого курсу полягає в ознайомленні студентів з теоретичними аспектами проблеми важковиховуваності як форми девіантної поведінки та набутті практичних навичок психодіагностичної, профілактичної, консультативної та психокорекційної роботи 3 вказаною категорією осіб. Навчальна дисципліна «Психологія важковиховуваних» складається 3 трьох змістових модулів, які утворюють три логічні блоки, призначені для ознайомлення зі специфікою роботи з підлітками, які мають поведінкові відхилення. За допомогою першого змістового модуля розширюються знання студентів щодо сутності та психологічних особливостей важковиховуваності, чинників деструктивної поведінки, індивідуально-психологічних, вікових та гендерних аспектів її виявлення. Другий змістовий модуль призначений для формування знань щодо роботи 3 підлітками, схильними до деструктивної поведінки та важко піддаються виховним впливам. Цей тематичний блок дає змогу студентам ознайомитись 3 особливостями психодіагностичної, профілактичної, консультативної та психокорекційної роботи з важковиховуваними дітьми та підлітками. Третій змістовий модуль націлений на конкретизацію знань майбутніх психологів щодо форм, методів і засобів роботи з окремими типологічними групами важковиховуваних.

Окреслений зміст навчальної дисципліни «Психологія важковиховуваних» має, на наш погляд, достатній психолого-педагогічний потенціал для формування когнітивного компонента готовності майбутніх психологів до роботи з підлітками девіантної поведінки у контексті розширення і систематизації знань щодо чинників, особливостей девіантної поведінки, психологічного супроводу підлітків, які визначаються такими поведінковими відхиленнями. Викладений висновок отримав підтвердження під час повторної перевірки знань майбутніх психологів, здійсненої після вивчення дисципліни. За результатами повторного тестування було виявлено, що рівень знань здобувачів 3 досліджуваної проблеми зріс на $8 \%$ (високим рівнем знань володіли перед іï вивченням $24 \%$, а після проходження 
курсу - 32 \% студентів). Водночас було зафіксовано зменшення кількісних показників низького рівня обізнаності з проблемою (із 36 \% до 24 \% відповідно) (рис.4).

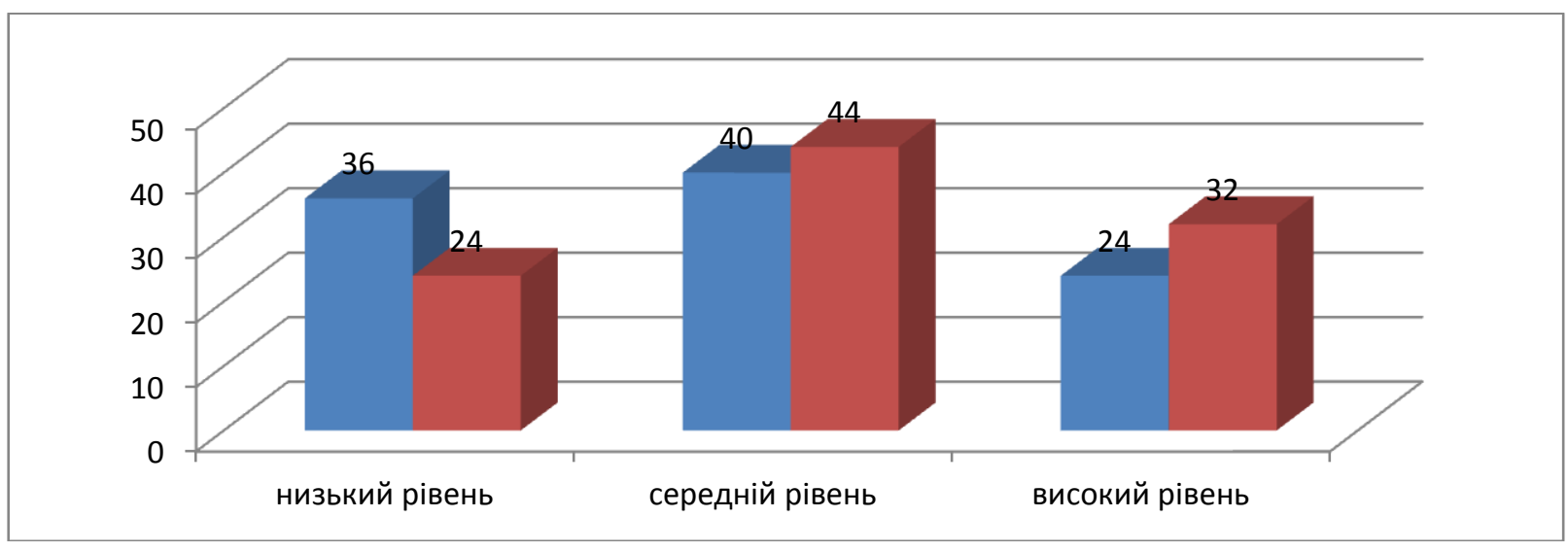

\section{Рис. 4. Порівняльні результати обізнаності здобувачів з проблемою девіантної поведінки до та після вивчення навчальної дисципліни «Психологія ваэковиховуваних" (у \%)}

Як бачимо, отримані емпіричні дані засвідчують результативність запропонованого курсу у плані підвищення обізнаності майбутніх психологів щодо проблеми девіацій загалом та можливостей роботи 3 девіантними підлітками зокрема. Помітними виявились зміни у самооцінках майбутніх психологів своїх пізнавальних можливостей щодо проблеми девіантної поведінки підлітків. Аудиторна та самостійна робота здобувачів, передбачена робочою програмою навчальної дисципліни «Психологія важковиховуваних», сприяла узагальненню та систематизації знань з відповідної проблеми, що позначилось на рівні їх самооцінки таким чином: за результатами повторної діагностики високий рівень самооцінки обізнаності задекларували 32 \% здобувачів (під час первинної діагностики таких було 24 \%), а кількість студентів з низьким рівнем самооцінки зменшилась 328 \% до і 16 \%. Як бачимо, запропонована навчальна дисципліна сприяла розширенню знань студентів щодо проблеми девіантної поведінки, підвищенню їхньої впевненості у своїх можливостях до здійснення допомоги девіантним підліткам, що позитивно вплинуло на покращення рівня готовності до роботи з підлітками, схильними до девіантної поведінки (у контексті вдосконалення iї когнітивного компонента). Тому удосконалення теоретичної підготовки майбутніх психологів у закладах вищої освіти шляхом впровадження навчальних дисциплін, що цілеспрямовано формують необхідну базу знань 3 питань девіантної поведінки, є однією 3 психолого-педагогічних умов формування їх готовності до роботи у вказаному напрямку.

Висновки і перспективи подальших розвідок. Здійснене дослідження, дало змогу розкрити психолого-педагогічний потенціал навчальної дисципліни «Психологія важковиховуваних» в аспекті підготовки майбутніх психологів до роботи 3 підлітками, схильними до девіантної поведінки. Очевидним стає те, що рівень готовності працювати 3 ними (зокрема у контексті формування іiї когнітивного компонента) значною мірою залежить від наявної у здобувача системи знань відносно проблеми. Результати діагностики підтвердили, що впровадження в освітній процес закладу вищої освіти проблемно орієнтованих навчальних дисциплін $\epsilon$ важливою умовою підвищення рівня готовності майбутніх психологів до роботи у вказаному напрямку. Зроблені узагальнення спонукають до подальшого вивчення психолого-педагогічних умов формування готовності майбутніх психологів до роботи з підлітками, схильними до девіантної поведінки.

\section{СПИСОК ПОСИЛАНЬ}

Баркаева, И. (2009). Психолого-педагогические условия формирования готовности педагогапсихолога к работе с девиантными подростками. (Автореф. дис. канд. пед. наук). Калининград. 
Дорогіна, О. (2004). Особливості превентивної роботи з важковиховуваними дітьми молодшого шкільного віку в загальноосвітніх школах-інтернатах. (Автореф. дис. канд. пед. наук). Тернопіль.

Драч, І., \& Чернишова, С. (2010). Особливості освітньої діяльності у сучасній вищій школі. Теорія та методика управління освітою, 3, 1-10.

Затворнюк, О. (2016). Формування у майбутніх психологів готовності до професійного самовдосконалення. (Дис. канд. пед. наук). Київ.

Ковалькова, Т. (2016). Формування готовності майбутніх психологів до професійної діяльності в авіаційній галузі у прочесі фахової підготовки. (Дис. канд. пед. наук). Київ.

Opoc, В. (2012). Психологічна специфіка агресивності у важковиховуваних акцентуйованих підлітків. Проблеми загальної та педагогічної психології, 24/6, 342-350.

Сердюк, Н. (2018). Педагогічні умови формування конкурентоздатності майбутніх психологів у процесі фахової підготовки. (Дис. канд. пед. наук). Тернопіль.

Тараненко, В. (2015). Роль корекційно-педагогічної діяльності у вихованні підлітків 3 девіантною поведінкою. Педагогічна освіта: теорія і практика, 18, 99-104.

Чаплак, Я. (2006). Формування готовності майбутніх практичних психологів до консультативної роботи із старшокласниками. (Автореф. дис. канд. психол. наук). Київ.

\section{REFERENCES}

Barkaeva, I. (2009). Psihologo-pedagogicheskie uslovija formirovanija gotovnosti pedagogapsihologa $\mathrm{k}$ rabote s deviantnymi podrostkami [Psychological and pedagogical conditions for the formation of the readiness of a teacher-psychologist to work with deviant adolescents]. (Avtoref. dys. kand. ped. nauk). Russian State University by Immanuel Kant. Kaliningrad. [in Russia].

Dorohina, O. (2004). Osoblyvosti preventyvnoi roboty z vazhkovykhovuvanymy ditmy molodshoho shkilnoho viku $v$ zahalnoosvitnikh shkolakh-internatakh [Features of preventive work with difficult children of primary school age in boarding schools]. (Avtoref. dys. kand. ped. nauk). Ternopil Volodymyr Hnatiuk National Pedagogical University, Ternopil. [in Ukraine].

Drach, I., \& Chernyshova, Ye. (2010) Osoblyvosti osvitnoi diialnosti u suchasnii vyshchii shkoli. [Features of educational activity in modern higher school]. Teoriia ta metodyka upravlinnia osvitoiu, 3, 1-10. [in Ukraine].

Zatvorniuk, O. (2016). Formuvannia u maibutnikh psykholohiv hotovnosti do profesiinoho samovdoskonalennia [Formation of Future Psychologists' Readiness to Professional Self Improvement]. (Dys. kand. ped. nauk). National Dragomanov Pedagogical University. Kyiv. [in Ukraine].

Kovalkova, T. (2016). Formuvannia hotovnosti maibutnikh psykholohiv do profesiinoi diialnosti v aviatsiinii haluzi u protsesi fakhovoi pidhotovky [Formation of Future Psychologists' Readiness for Professional Work in Aviation Industry in the Process of Professional Training]. (Dys. kand. ped. nauk). National Aviation University. Kyiv. [in Ukraine].

Oros, V. (2012). Psykholohichna spetsyfika ahresyvnosti u vazhkovykhovuvanykh aktsentuiovanykh pidlitkiv [Psychological specifics of aggression in difficult-to-educate accentuated adolescents]. Problemy zahalnoi ta pedahohichnoi psykholohii, 24/6, 342-350. [in Ukraine].

Serdiuk, N. (2018). Pedahohichni umovy formuvannia konkurentozdatnosti maibutnikh psykholohiv u protsesi fakhovoi pidhotovky [Pedagogical conditions of formation of competitiveness of future psychologists in the process of professional training]. (Dys. kand. ped. nauk). Ternopil Volodymyr Hnatiuk National Pedagogical University. Ternopil. [in Ukraine].

Taranenko, V. (2015). Rol korektsiino-pedahohichnoi diialnosti u vykhovanni pidlitkiv z deviantnoiu povedinkoiu [The role of correctional and pedagogical activities in the 
education of adolescents with deviant behavior]. Pedahohichna osvita: teoriia i praktyka, 18, 99-104. [in Ukraine].

Chaplak, Ya. (2006). Formuvannia hotovnosti maibutnikh praktychnykh psykholohiv do konsultatyvnoi roboty iz starshoklasnykamy [Formation of readiness of future practical psychologists to consultative work with senior pupils]. (Avtoref. dys. kand. psykhol. nauk). Institute of Pedagogic and Psychology of Professional Education, APS of Ukraine, Kyiv. [in Ukraine].

\title{
PSYCHOLOGICAL AND PEDAGOGICAL POTENTIAL OF THE "PSYCHOLOGY OF INTRACTABLE CHILDREN" COURSE IN THE ASPECT OF FUTURE PSYCHOLOGISTS' TRAINING TO WORK WITH THE ADOLESCENTS PRONE TO DEVIANT BEHAVIOUR
}

\author{
Halyna Lutsyk \\ Lecturer at the Department of Developmental and Pedagogical Psychology \\ Rivne State University of the Humanities \\ https://orcid.org/0000-0003-3905-2038
}

DOI https://doi.org/10.35619/praprv.v1i16.228

\begin{abstract}
The article analyses the content of the cognitive component of the future psychologists' readiness to work with adolescents prone to deviant behaviour and considers cognitive component's indicators. It is revealed that the cognitive component of future psychologists' readiness to such work includes knowledge of basic concepts and theoretical approaches to understanding deviant behaviour, knowledge of basic categories that characterize the features of working with adolescent deviant behaviour, knowledge of forms and methods of working with adolescent deviant behaviour in psychodiagnostic, preventive, consultative and psychocorrectional aspects, knowledge of the means of work as a psychologist with adolescents prone to deviant behaviour and self-assessment of the level of awareness about peculiarities of working with adolescents prone to deviant behaviour.

The results of a study of the levels of future psychologists' awareness about the problem of deviant behaviour of adolescents are highlighted. Due to the fact that the level of development of the cognitive component of the future psychologists' readiness to work with adolescents prone to deviant behaviour is insufficient to work effectively, the process of undergraduates' training in higher education institutions needs to be improved. It is determined that one of the psychopedagogical conditions for the formation of future psychologists' readiness to work in this area is the gradual enrichment of the professional training content based on the integration of psychopedagogical potential of educational disciplines and special courses. Based on the analysis of scientific works it is found that difficult upbringing in the modern psychological literature is considered as a separate form of deviant behaviour. It is stated that teaching of the discipline "Psychology of difficult children" has a significant psycho-pedagogical potential in the process of forming the future psychologists' readiness to work with adolescents prone to deviant behaviour. According to the results of re-diagnostics of levels of future psychologists' awareness about the problem of adolescent deviant behaviour, the content of the discipline expands students' knowledge of the main categories of deviant behaviour, acquaints with the basic forms and methods of work, develops skills of psychodiagnostic, preventive, consultative and psychocorrectional work with adolescent deviant behaviour.

Key words: adolescents, deviant behaviour, future psychologists, adolescents prone to deviant behaviour, future psychologists' readiness, formation of future psychologists' readiness to work with adolescents prone to deviant behaviour, cognitive component of future psychologists' readiness to work with adolescent deviant behaviour, psycho-pedagogical potential of the discipline, difficult children, psychology of difficult children.
\end{abstract}

